\title{
Research on Military and Civilian Integration Development Strategies of General Aviation Industry in the New Era
}

\author{
Liang Zhang ${ }^{1,}$, Yantao Wang ${ }^{2, b}$ \\ ${ }^{1}$ Airport Operation Management Department, Guangzhou Civil Aviation College, Guangzhou, China \\ ${ }^{2}$ Civil Aviation University of China, Tianjin, China \\ a25267764@qq.com, b40435611@qq.com
}

Keywords: Military and Civilian Integration, General Aviation.

\begin{abstract}
As a national strategic emerging industry, the general aviation industry plays an important strategic role in promoting sustainable development of economy and society and promoting modernization construction in the new era. This thesis analyzes the theory of military and civilian integration development of the general aviation industry, dissects the significance of the military and civilian integration development of the general aviation industry in the new era, and finally proposes the development strategy of military and civilian integration of China's general aviation industry in the new era.
\end{abstract}

\section{The Origin and Meaning of China's Military and Civil Integration}

The idea of China's military and civilian integration is the inheritance and development which the different generations of leading group on the military and civilian integration idea. At the beginning of the new China, Mao Zedong as the core of the leading group of the party, strengthen the economic construction at the same time, the national defense construction is put in a more prominent position, and establish that national defense science and technology industry carry out the military and civilian integration, peacetime and wartime integration, take army as the principal thing; after Chinese eleventh CPC Central Committee Third Plenary Session, the requirements proposed by Deng Xiaoping are: "military and civilian integration, peacetime and wartime integration, military products have priority, civilian support army", the key point of practice is military technology to civil use [1]; since the Chinese thirteenth CPC Central Committee Fourth Plenary Session, the requirements proposed by Jiang Zemin are " military and civilian integration". Since the 17th National Congress of the CPC, Hu Jintao has established a strategic thinking "walk a development road of military and civilian integration with Chinese characteristics", integrate national defense and military modernization construction into the economic and social development system deeply, and further gives play to the facilitation of national defense science and technology for national economy. Since the 18th National Congress of the CPC, General Secretary Xi Jinping has emphasized many times, the military and civilian integration rises to national strategy, it is necessary to carry out military and civilian integration ideas and requirements into the entire process of economic construction and national defense construction and accelerate the formation of military and civilian deep integration development pattern with total factor, various fields, and high efficiency [3].

\section{The Significance of the Military and Civilian Integration Development of the General Aviation Industry in the New Era}

President Xi Jinping pointed out in report of the 19th session of national congress of the communist party of China: "The socialism with Chinese characteristics has entered a new era, it is a new historical orientation for China's development” [4]. In the new era, the full implementation of the military and civilian integration development of general aviation industry, which has strategic significance for realizing the balanced development of national economy and the coordinated development of national defense forces. 
(1) The military and civilian integration is a new important force for promoting comprehensive and balanced economic development

Our country attaches great importance to the public transport flight for a long time, ignore the general aviation industry development, cause the disorder and blindness in the development of China's general aviation industry, unreasonable industry planning causes the general aviation industry development to be slow, the core competitiveness is weak and many deep problems emerge in an endless stream, unbalanced and insufficient problems are very obvious in general aviation industry development in different regions.

The military and civilian integration development of general aviation industry can effectively solve the problems of streamline administration and institute decentralization with slow pace and low operational efficiency, which is represented by the low-altitude airspace reform. General aviation industry guidance policy is not strong, the law is not high; operability of guidance policy of general aviation industry is not strong, the law is not high; innovative ability of general aviation industry is not strong, the enterprises' innovative power is seriously insufficient, safety operation situation of general aviation is serious, safety challenge problems of industrial development, the general aviation talent pool is not enough, the quality of talent training is not high and a series of problems. The solution of these problems, the general aviation industry will develop comprehensively, which will become a new power to promote the overall development of China's economy.

(2) Military and civilian integration is an important supporting force for realizing the modernization of national defense.

Since the 18th CPC National Congress, China's national defense modernization cause has blossomed, great progress has been made in the information construction, and there is a big improvement in strategic ability, which has become a solid backing to protect our homes and defend our country. However, China's national defense modernization started late; there are still some contradictions between the efficiency of national defense construction and the development requirement of national defense modernization.

The military and civilian integration development of general aviation industry can effectively solve many problems, for example, China's national defense innovation capability mainly based on basic research and development and production capacity is not strong, the comprehensive quality and the construction pace of national defense talents do not match the requirements of the new era, there is a gap between the existing national defense construction efficiency and the development requirement of national defense modernization in the new era, the investment scale of new technology research and development does not match with the requirement of national defense information construction in the new era. The solution of these problems will add vigor to the further development of China's national defense modernization and provides important support for comprehensively promoting the modernization of military theory, modernization of military organization form, modernization of military personnel, modernization of weapons and equipment.

\section{The Development Strategy of Military and Civilian Integration of General Aviation Industry in the New Era}

The military and civilian integration of China's general aviation industry is a systematic project, which involves country, army, places, government, enterprises and individuals and many interest subjects with different levels and types, need overall planning and comprehensive consideration, then we can truly achieve the healthy development of China's general aviation industry, military and civilian integration. Based on the present situation of the military and civilian integration development of China's general aviation industry and draw lessons from the advanced ideas and mature experience of military and civilian integration of emerging industries in developed countries, the author thinks that the military and civilian integration development strategy of China's general aviation industry should be carried out around the following aspects in the new era.

(1) Set up the ideology of military and civilian integration development of general aviation industry 
First, we should set up "big navigation", "big national defense" and "deep integration" idea. Every interest subject should treat the military and civilian integration development of general aviation industry in this way. "Big navigation" takes "takeoff" as the pull, delegate power and strengthen regulation, promote the opening of low-altitude airspace as the handle, simplify the approval process of general aviation, promote low-altitude airspace guarantee and service ability, realize general aviation "visible, connected, controllable" development model; "big national defense" regard the military and civilian integration development of general aviation as promoting comprehensive improvement of national defense forces, one of the cornerstones of safeguarding national security, and use for the common people in peacetime, during the war, it could become an important national defense force, "deep integration" converts the various resources of flight support divided by the military and civilian into the efficient resources of the two-way interaction between the military and the people, maximize the national defense capability, promote the rapid development of general aviation industry.

Second, it is necessary to fully realize that the military and civilian integration development of general aviation industry is of great significance to promoting the development of general aviation industry and achieving rich country and strengthen army. General aviation industry must break "military and civilian separation" and "closed and independent" industrial development thinking, the general aviation industry is developed into a new engine of future China's economic development, it is the important guarantee of national defense strategic security, achieve national security and social economy develop harmoniously, promote each other.

Third, we must establish the overall situation idea that local interests subordinated to the overall interests. The military and civilian integration development of general aviation industry is related to local interests, departmental interests, enterprise interests, and personal interests in addition to national defense security. The interest appeals of every subject are not identical, and every subject wants to maximize the benefits in the development process. It is inevitable to be contradictions. Therefore, every interest subject should set up the overall situation idea of "removes individual for the sake of overall situation".

(2) Perfect the system and mechanism for the military and civilian integration development of general aviation industry

First, we must perfect the top-level design and deepen the reform of the military and civilian integration system of general aviation industry. The military and civilian integration development of general aviation industry involves the military system, the civil aviation system, relevant ministries, various departments and units; it concerns the interest relationship between government and army, enterprise and army, government and enterprise and so on. Top-level design is standing on the height of the national defense strategy, form military and civilian integration system of general aviation industry, accelerate the operation system that national guidance, demand pull and market operation unify, speed up the achievement of policy system with complete system and efficient drive [6].

Second, we should establish military and civilian integration development system which can promote aviation industry. The essence of military and civilian integration development of general aviation industry is the process which various resources among military and navigation, military enterprises and general aviation enterprises are continually recombined and used. Specifically, institutional environment of the military and civilian integration development of general aviation industry is optimized, military and civilian integration type, first, public system of military and navigation resource sharing is further established, clarify the respective responsibilities and obligations of the two parties; second, the institutional barriers and bottleneck of the development of the general aviation industry by the army are broken, streamline administration and delegate power to the lower levels, and solve the problem of institutional contradictions.

Moreover, the related mechanism of military and civilian integration development and operation of general aviation industry is designed; ensure the effectiveness of resource allocation. First, the roles of plans and markets are coordinated, relying on the regulation of the market mechanism in demand and supply, and realize the military and civilian integration development of the general aviation industry; second, design scientific incentive, competition, supervision and evaluation 
mechanism are design, supervise and manage the content of military and civilian integration of general aviation industry, third, perfect the infrastructure construction of military and civilian integration development of general aviation industry, the related social supporting mechanism of terminal market cultivation and talent cultivation, and promote the durability, continuity and normality of military and navigation integration.

(3) Perfect the laws system of military and civilian integration development of general aviation industry

First, a set of systematic and perfect laws system of military and civilian integration of general aviation is formulated. The national level, consider publishing "The Promotion Law of the Military and Civilian Integration of People's Republic of China " as state-level basic law of the various fields and industries of military and civilian integration, the army and the civil aviation authority level, consider publishing " Plan of Military and Civilian Integration Development of General Aviation Industry", specify the specific details and management measures of the military and civilian integration of general aviation industry, local laws and regulations and the level of local government departments, according to the needs of the military and civilian integration development of the general aviation industry in the region, publish a series of policies to promote the integration military and civilian of the general aviation industry in the region, in this way, the interrelated, complementary military and civilian integration development laws and regulations system of general aviation industry are constituted from the national level, the military and industry departments, the local government level, there must be laws for people to follow.

Second, the compatible development of military standard system and the civilian standard system is achieved. The policy is published from the national level, guide and encourage the military and civilian standard reform. Leading technology has been achieved in the field of general aviation should be included in the military standard system as much as possible, gradually achieve the military and civilian integration of standard system.

(4) Establish and perfect the scientific and technological innovation system for the military and civilian integration of general aviation industry

First, we must eliminate the boundaries between the field of military scientific research innovation and the field of general aviation industry innovation and achieve the deep integration of the military scientific research innovation system with the general aviation industry innovation system. Through the establishment of the systematic policy system, the government, army and enterprises can jointly carry out the general aviation technological innovation, and jointly promote the coordinated development of the national defense scientific research strength and the scientific research strength of general aviation industry.

Second, we should set up technological innovation alliances, which are mainly composed of core general aviation enterprises, supplemented by industry research institutes, deep involvement of the military, guided by market economy, navigation products as the core, industry and education are integrated. Through the establishment of stable and effective way cooperation between the military and navigation two sides, we should strive to promote the scientific research achievements shared and developed in the general aviation field and the military field.

(5) Co-build talent training system of military and civilian integration development of general aviation industry.

First, we should renew the idea and correctly establish the training goal and strategic position of military and civilian integration of the general aviation industry. The first is to stand in the strategic height and recognize the strategic role of the military and civilian integration talents of general aviation industry, and the significance of military and civilian integration talent training of general aviation industry, establish the enhancement of military and civilian integration talent training of general aviation industry is the strong support for improving the guarantee efficiency and promote industrial upgrading, the second is to correctly establish the goal requirements, guiding ideology, method and principles for the talents training of military and civilian integration of general aviation industry, third, we must establish comprehensive training idea and advancing training idea, and train 
talents who understand the related knowledge of the general aviation industry and the relevant knowledge of national defense.

Second, the model is reformed to achieve "three transformations" of military and civilian integration talent training of general aviation industry. The first is to change "closed type" to "open type". We should adhere to the "use for me" principle; industry colleges and defense colleges fully cooperate and share resources to carry out the talent training of military and civilian integration. Second, we need to train in advance to meet the general aviation industry's demand for talent, and we must fully investigate to meet the army's demand for general aviation talents.

Third, the mechanism is constructed and comprehensively improves the performance of the military and civilian integration talent training of general aviation industry. First, we need to build the training mechanism for the military and civilian integration of general aviation industry and provide a convenient education service for the talents' training, second, it is necessary to construct the incentive mechanism, we will conduct regular evaluation on the units that implement the talent training of military and civilian integration of general aviation industry and form a good environment for talent training.

\section{References}

[1]. Ji Zhongren. Persistently pave the way for rich country and strong military--review and prospect of the military and civilian integration practice with Chinese characteristics[J], Defense Industry Conversion in China, 2015(7).

[2]. Xu Sutu, Zhang Xiaoping. The "civil-military integration" talent training system based on discipline construction and information resources sharing[C]// China Association for Science and Technology, 2013.

[3]. Xin Foshan. Closely focus on the reform and strong military and strive to promote the in-depth integration and development of national defense mobilization and reserve forces. [J]. National Defense, 2016(8):4-7.

[4]. http://cpc.people.com.cn/19th/n1/2017/1018/c414305-29594207.html

[5]. http://www.sohu.com/a/122411858_472861

[6]. Cao Chao, Du Renhuai. Deepen the "Three Systems" Reform and Innovation of the Military and Civilian Integration Development [J], Theoretical Studies on PLA Political Work, 2016, 17(1). 